Иван Н. Петров (Лодзь)

\title{
ИЗДАНИЯ БИБЛЕЙСКИХ ТЕКСТОВ В ЮЖНОСЛАВЯНСКОЙ КИРИЛЛОВСКОЙ СТАРОПЕЧАТНОЙ ТРАДИЦИИ XVI ВЕКА
}

Б иблейские тексты принадлежат к корпусу южнославянских старопечатных источников как в виде изданий отдельных текстов, так и в качестве фрагментов книг, в которых тот или иной библейский текст является не основой издания, а лишь одним из составляющих основного (чаще всего, литургического) жанра. В данной статье внимание будет сосредоточено на памятниках первой группы: ранних южнославянских печатных изданиях кирилловского (или кириллического) шрифта, содержащих отдельные библейские книги и издававшихся прежде всего в XVI веке. Эти источники представляют собой образцы и примеры основных палеотипических южнославянских традиций: черногорской и сербской, румыно-болгарской, венецианской ${ }^{1}$. Стоит отметить, что наравне с определением «старопечатная книга» в настоящей статье используется термин «палеотип» (и производные от него), который представляется вполне удобным и емким и который встречается, хоть и не часто, в отдельных исследованиях, посвященных проблематике старопечатных славянских изданий ${ }^{2}$.

Стоит подчеркнуть, что издания, о которых пойдет речь, вписываются в раннюю историю кирилловской палеотипии в целом и являются частью довольно большого по размерам и важного, но в то же время пренебрегаемого, как представляется, корпуса источников. Обыкновенно исследователи (по крайней мере, до последнего времени), которые в своих работах в той или иной степени затрагивают начало славянского книгопечатания кирилловским шрифтом, сосредотачивают внимание на краковских инку-

\footnotetext{
${ }^{1}$ На тему типологии старопечатных южнославянских традиций см., напр.: И. БогдАнов, Български първопечатни книги от XVI-XVIII вв., ГББИ 9, 1963, р. 85-123, IDEм, Българската книга през вековете, София 1978, p. 182-196; I. Ретrov, Od inkunabułów do pierwszych gramatyk. Konteksty rozwoju bułgarskiego języka literackiego (koniec XV - początek XVII wieku), Łódź 2015, p. 79-84.

${ }^{2}$ См., напр., М. Цивранска-КостовА, Етюди върху кирилската палеотипия XV-XVIII век, София 2007; Е.Л. НЕмиРовскиЙ, Иван Федоров и его эпоха: энииклопедия, Москва 2007, p. 562; М. ЦивранскА-Костова, Сборникбт „Различни потреби” на Яков Крайков между Венеция и Балканите през XVI век, София 2013.
} 
набулах Швайпольта Фиоля (1491) и прежде всего на восточнославянской палеотипической традиции (Франциск Скорина, Иван Федоров и др.), придавая существовавшему до появления Острожской Библии (1581) и активно развивавшемуся в XVI веке кирилловскому книгопечатанию для южных славян и румын значительно меньшее значение. Свидетельством тому является отсутствие монографических исследований в этой области - нет синтетических работ ни на тему венецианского издательского дома Божидара и Виченцо Вуковичей и их последователей (1519-1638), ни на тему румыно-болгарских (и собственно румынских) палеотипов, издававшихся во второй половине XVI века дьяконом Кореси и его учениками и соратниками (1557-1588). Конечно, существуют отдельные работы (прежде всего текстологические и лингвистические), посвященные конкретным источникам, однако в целом, особенно по сравнению с издававшимися в этот же период восточнославянскими печатными книгами, южнославянская палеотипическая традиция довольно мало изучена.

А ведь появление и развитие кирилловской печати, что очевидно, не только переориентировало текстологическую и переводческую стратегию многих издателей того времени, включая издателей библейских текстов. Оно также коренным образом повлияло на процессы языкового характера. Ведь именно с кирилловским книгопечатанием связывают такой важный для apeала Slavia Orthodoxa феномен, как появление т.н. ново-церковно-славянского языка (или церковнославянского языка Нового времени), его кодификацию в грамматиках конца XVI и начала XVII вв. (Лаврентий Зизаний, Мелетий Смотрицкий и другие), а также его позднейшую роль в становлении национальных языков православных славян, прежде всего болгар и сербов. Если мы согласимся со мнением Н.Б. Мечковской, что появление грамматики любого языка является не начальным, а скорее конечным этапом определенной фазы его развития ${ }^{3}$ и соотнесем его с кодификационными процессами церковнославянского языка, то мы вынуждены будем признать, что значение старопечатной традиции XVI в. - как восточнославянской, так и южнославянской, а также их взаимосвязи - это вопрос, которым не стоит пренебрегать.

В начале презентации южнославянских изданий библейских текстов стоит сказать несколько слов о выходивших параллельно с кирилловскими глаголических книгах, предназначенных прежде всего для католических и протестантских общин. Согласно сводному каталогу глаголических печатных книг московского исследователя Андрея Круминга ${ }^{4}$, до конца XVI века были изданы лишь две глаголические книги с библейскими текстами

\footnotetext{
${ }^{3}$ Н.Б. МечковскАя, Ранние восточноставянские грамматики, Минск 1984, р. 32.

${ }^{4}$ А.А. Круминг, Сводный каталог старопечатных изданий глаголического шрифта 14831812 г2., Москва 1998.
} 
(конечно, если не считать отдельных фрагментов, содержащихся в миссалах, бревиариях и других изданиях).

Первое глаголическое издание, в котором содержание библейских текстов обозначено уже на уровне заглавия (номер 18 в каталоге Круминга), - это Псалтырь хорватской редакции, вышедшая не ранее 1531 года в городе Фиуме (ныне Риека), в типографии Шимона Кожича. Стоит отметить, однако, что в действительности это сборник различных текстов (сам Круминг называет его печатным глаголическим букварем $\left.{ }^{5}\right)$, среди которых, помимо азбуки и молитв, помещены псалмы 42, 50, 90, 109-113, а также новозаветные Песнь Богородицы и Песнь Симона Богоприимца из Евангелия св. Луки. Следующим глаголическим библейским изданием было „первое издание Нового Завета на хорватском языке”, гене у Примуса Трубера (номер 24). Подчеркнем, что в 1563 г. в Тюбингене вышло еще одно издание Нового Завета на хорватском языке, напечатанное уже кириллицей ${ }^{7}$.

Если говорить непосредственно об основных палеотипических традициях раннего южнославянского кирилловского книгопечатания для православных славян и румын, то они могут быть прослежены и очерчены прежде всего благодаря изданным в последние десятилетия сводным каталогам Евгения Немировского ${ }^{8}$ и Александры Гусевой (ниже в скобках перед каждым источником указывается порядковый номер по каталогу - соответственно $\mathrm{N}$ и G). Традиции эти (в хронологическом порядке) представлены следующими изданиями библейских текстов:

\footnotetext{
${ }^{5}$ Ibidem, p. 44.

${ }^{6}$ Ibidem, p. 53.

7 Л.И. Сазонова пишет об этом издании так: Сразу вслед за глаголическим изданием на хорватском языке (1562/1563) вышел основанный на словенском переводе Трубера перевод [...], адресованный и католикам, и православным [...]. На Балканах соседствовали славяне разных конфессий, включая мусульманство, они не только граничили друг с другом, но и, пересекаясь, жили в тесном контакте, как, например, в районах современной Боснии. По замыслу протестантского проповедника, изданный им перевод Нового Завета должен был послужить укрептению ставян в христианской вере и спасению их от опасности истамизации. (Л.И. САзонова, Книги кириллической печати во второй половине XVI века между Римом и Москвой, [in:] А.А. ГусевА, Издания кирилловского шрифта второй половины XVI века. Сводный каталог, vol. I-II, Москва 2003, р. 1244).

${ }^{8}$ Немировский издал две серии каталогов (обе еще не завершены), т.н. немецкий (до конца первой половины XVI в.) и т.н. московский: E.L. NeмirovsкiJ, Gesamtkatalog der Frühdrucke in kyrillischer Schrift, vol. I-VII, Baden-Baden 1996-2007; Е.Л. Немировский, Славянские издания кирилловского (иерковнославянского) шрифта 1491-2000. Инвентарь сохранивщихся экземпляров и указатель литературы, vol. I, 1491-1550, Москва 2009; vol II.1, 1551-1592, Москва 2011; vol. II.2, 1593-1600, Москва 2012.

${ }^{9}$ А.А. ГУСевА, Издания кирилловского шрифта второй половины ХVI века. Сводный каталог, vol. I-II, Москва 2003.
} 
Первым представителем является один из четырех инкунабулов, изданных Джураджем Црноевичем в черногорском Цетинье:

(N: 7) Псалтырь с восследованием, 22 сентября 1495, 348 л., 31 экз. и фрагм.

В научной литературе существует мнение о возможном существовании еще одного черногорского библейского инкунабула - т.н. цетинском Четвероевангелии. Основано оно на ошибочных, скорее всего, упоминаниях в некоторых каталогах и описаниях, изданных еще в XIX веке, а также на интерпретации ряда т.н. анаграфических текстов (предисловия, послесловия, колофоны) иных изданий XVI века. Немировский и Гусева относят существование цетинского Четвероевангелия (а также ряда других несохранившихся черногорских инкунабулов) к вопросам не только спорным, но и весьма сомнительным, а Немировский и вовсе в некоторых своих публикациях решительно называет утверждения об этом издании, повторяющиеся в работах прежде всего сербских и черногорских исследователей, научной легендой ${ }^{10}$.

Палеотипическую традицию изданий XVI века, предназначенных для южных славян и румын, открывает румыно-болгарская (валашская) типография иеромонаха Макария, в которой были изданы три книги, в том числе известное Тырговиштское Четвероевангелие:

(N: 11) Четвероевангелие, 26 июля 1512, 293 л., 23 экз. и фрагм.

Нет никаких сомнений, что этот палеотип был самым важным изданием типографии Макария. Во-первых - это первое печатное издание новозаветного библейского текста в ареале Slavia Orthodoxa (если не брать во внимание упомянутую выше гипотезу, касающуюся цетинского Четвероевангелия). Во-вторых - это издание оказало огромное влияние на дальнейшее развитие южнославянского книгопечатания - как в румынских, так и сербских землях. Как указывает Немировский,

в течение многих десятилетий Четвероевангелие 1512 г. старательно копировали на южнославянских землях как рукописным, так и типографским способом. Валашское издание является оригиналом для Четвероевангелий, напечатанных в 1537 г. в монастыре Руйно, в 1552 г. - в Белграде и в 1562 г. в монастыре Мркшина Црква. Использовалось оно и для Евангелий, печатавшихся на территории Валахии. Надо сказать, что последующие типографы копировали не только текст, но и орнаментальные украшения издания 1512 года ${ }^{11}$.

Лингво-текстологические исследования этого палеотипа были проведены болгарской исследовательницей Дианой Ивановой, которая в своих работах использует метод хронологической проекции языковых черт

${ }^{10}$ Е.Л. НЕмировский, История славянского кирилловского книгопечатания XV - начала XVII века, vol. II, Начало книгопечатания у южных славян, Москва 2005, pars 2, p. 485-504.

${ }^{11}$ Е.Л. НЕмировский, Славянские издания..., vol. I, p. 84. 
данного издания на предшествовавшие его появлению южно- и восточнославянские евангелические рукописные памятники (в том числе на Геннадиевскую Библию 1499 года), а также на более поздние (южные и восточные) печатные кодексы с библейскими текстами, как: Острожская Библия 1580-1581, ее московское переиздание 1663 г. (т.н. Московская Библия), ее петербургское переиздание 1751 года (т.н. Елизаветинская Библия). Выводы этих исследований относятся как к истории самого славянского библейского текста, так и к роли южнославянской составляющей в процессе формирования церковнославянского языка Нового времени:

\footnotetext{
Анализът на текста и езиковите средства показва, че по-късните църковнославянски преводи не са изолирани нито от старата ръкописна традиция, нито от предходните печатни книги [...]. Очевидна е рецепцията на българската печатна книга от XVI век върху по-сетнешните църковнославянски преводи, отпечатвани в края на XVI и през XVII-XVIII век в Русия и Украйна. Променени фонетично и редактирани, те отново се връщат и разпространяват широко в България ${ }^{12}$.
}

После издания Тырговиштского Евангелия румыно-болгарская печатная традиция на несколько десятилетий прерывается, а на первый план выдвигается издательская деятельность жившего в Венеции сербского книгоиздателя Бодижара Вуковича, основавшего просуществовавшую почти век (с перерывами) типографию. Среди первых книг, изданных Вуковичем, фигурируют два издания Псалтыри:

(N: 24) Псалтырь, 7 апреля 1519, 160 л., 6 экз. и фрагм.

(N: 38) Псалтырь с восследованием, 12 октября 1520, 352 л., 51 экз. и фрагм.

Вторая из этих книг была дважды переиздана после смерти Божидара его сыном Виченцо Вуковичем, причем типографическое оформление этих изданий было чрезвычайно богатым:

(N: 75) Псалтырь с восследованием, 1546, 308 л., 73 экз. и фрагм. [переиздание Псалтыри 1520 г. (N: 38)].

(N: 100: G: 21) Псалтырь с восследованием, 1561, 284 л., 32 экз. и фрагм. [переиздание Псалтыри 1546 г. (N: 75)].

Псалтырь с восследованием издают также последователи Вуковичей, работавшие в их типографии во второй половине XVI века - Йеролим Загурович и Яков Крайков:

(N: 130; G: 46) Псалтырь с восследованием, 1569-1570, 276 л., 55 экз. и фрагм.

Эта же библейская книга стала последним отголоском венецианской палеотипической кирилловской традиции: в основанном уже в XVII веке

\footnotetext{
${ }^{12}$ Д. Иванова, Традиция и приемственост в новобългарските преводи на Евангелието. Текстология и език, Пловдив 2002, р. 96.
} 
издательском доме династии Бартоломео, Марка и Бартола Джинамми (Ginammi) было в 1638 году выпущено переиздание Псалтыри с восследованием, сделанное на основе издания Загуровича и Крайкова:

Псалтырь с восследованием, 1638, 276 л., 34 экз. и фрагм. [переиздание Псалтыри с восследованием 1569-1570 г. (N: 130)] ${ }^{13}$.

Практически одновременно с венецианской традицией южнославянского кирилловского книгопечатания возникла традиция сербская, связанная прежде всего с деятельностью нескольких монастырских типографий. В рамках этой традиции, помимо Псалтыри, было издано несколько четвероевангелий.

В качестве первой книги данной традиции модно указать на Псалтырь с восследованием, выпущенную в Горажде (город на территории нынешней Республики Боснии и Герцеговины) Феодором Любавичем, сыном Божидара Любавича, начало книгоиздательской деятельности которого некоторые исследователи связывают с Венецией:

(N: 39/40) Псалтырь с восследованием, 25 октября 1521, 352 л., 10 экз. и фрагм.

Спустя несколько лет возникает первая известная по сохранившимся источникам сербская монастырская типография - Руйна, которая выпускает в 1537 г. Четвероевангелие:

(N: 66) Четвероевангелие, 1537, 302 л., 5 экз. и фрагм.

Подробный анализ типографических особенностей сохранившихся экземпляров, размеров шрифта, а также графики и орнаментики, убеждает исследователей в том, что монах Феодосий, печатавший Четвероевангелие в монастыре Руйно использовал в своей работе румыно-болгарское Тырговиштское евангелие 1512 года. Приведу слова Е. Немировского:

вне всякого сомнения, в руках у Феодосия было валашское Четвероевангелие 1512 г., откуда он скопировал некоторые свои заставки. Состав обоих изданий одинаков. Вступительной молитвы перед чтением Евангелия или же известия о так называемом четвертичном числе Евангелий, которые есть, например, в московских безвыходных Четвероевангелиях, ни в валашском, ни в руянском изданиях нет. Между тем орфография в обоих изданиях различна. В валашском издании мы встречаем болгарское правописание с характерными для него юсами, в руянском - сербское без юсов ${ }^{14}$.

Добавлю, что Руянское Четвероевангелие 1537 г. является одним из трех сохранившихся кириллических палеотипов первой половины XVI века, содержащих текст четырех Евангелий (помимо Тырговиштского и его переиздания,

${ }^{13}$ Е.Љ. Немировски, Издаюа Божидара и Вићениа Вуковића, Стефана Мариновића, Јакова од Камене Реке, Јеролима Загуровића, Јакова Крајкова, Бованиа Антониа Рампацета, Марка и Бартоломеа Ђинамиа (1519-1638), Цетиње 1993, р. 195-196 (издание описано в каталоге под номером 28). ${ }^{14}$ E.L. NemirovsкiJ, Gesamtkatalog der Frühdrucke..., vol. VII, Baden-Baden 2007, p. 109-110. 
выпущенного в 1546 году Филиппом Молдаванином, о чем будет упомянуто ниже). Во второй половине столетия таких изданий было уже более десяти.

Следующим монастырским центром, выпускавшим в XVI веке печатные библейские книги, была обитель Милешева (недалеко от города Приеполя в юго-западной Сербии), где два раза была издана Псалтырь с восследованием:

$(\mathrm{N}: 70)$ Псалтырь с восследованием (т.н. первая), 30 октября 1544, 350 л., 24 экз. и фрагм.

(N: 88; G: 7) Псалтырь с восследованием (т.н. вторая), 4 ноября 1557, 294 л., 16 экз. и фрагм.

Издание 1544 г. в значительной степени копирует издание Божидара Вуковича 1520 г., в особенности с точки зрения формата книги, ее орфографии и акцентуации, используемых сокращений и надстрочных знаков. Однако между двумя изданиями можно все-таки найти целый ряд различий, хотя бы в очередности содержания дополнительной части или же в анаграфических текстах (послесловиях и колофонах), где, конечно же, указываются различные выходные и фактографические данные.

Несмотря на то, что монастырем Милешева на протяжении нескольких десятилетий руководил один и тот же игумен Даниил, в истории типографии этой обители можно выделить два этапа, поскольку в середине XVI века наступает радикальная перемена издательской практики (прежде всего в отношении используемых шрифтов и элементов орнамента). Стоит отметить, что издание 1557 г. - это вовсе не перепечатка Псалтыри 1544 года, а практически новое издание. Скорее всего, над подготовкой этой книги трудились совсем другие монахи, хотя в послесловии их имена не упоминаются.

В этом месте стоит сказать об одном загадочном издании Псалтыри ок. 1550 г., которое вышло в анонимной (скорее всего, сербской) типографии и сохранилось только во фрагментах всего лишь в двух экземплярах, находящихся в настоящее время в Белграде и Новом Саде:

(N: 78) Псалтырь, ок. 1550, более 80 л., 2 экз. и фрагм.

Шрифты, которые были использованы для издания этой Псалтыри, не встречаются ни в одном из известных сегодня кирилловских палеотипов, хотя некоторые исследователи указывают на возможные параллели между этой книгой и венецианскими изданиями Вуковичей ${ }^{15}$.

Во второй половине XVI века, помимо второй милешевской, действовали еще две сербские типографии - обе связанные с иеромонахом по имени Мардарий. Первая из них, известная в научной литературе под названием Белградская типография, выпустила лишь одну книгу:

(N: 82; G: 2) Четвероевангелие, 4 августа 1552, 212 л., 60 экз. и фрагм.

\footnotetext{
${ }^{15}$ Более подробно об этом издании и о сербских монастырских изданиях в целом см.: Е.Л. НЕмировский, Сербские монастьрские типографии 16 века, Москва 1995.
} 
Так же, как это случалось во время работы над многими выше представленными палеотипами, создатели Белградского Четвероевангелия использовали в качестве образца издания своих предшественников. На основе графических черт и орнамента, а также некоторых языковых особенностей (прежде всего графических и фонетических) можно утверждать, что Мардарий пользовался румыно-болгарским Тырговиштским Евангелием 1512 года. Стоит также отметить, что среди других образцов Белградского Четвероевангелия, некоторые сербские исследователи указывают на несохранившееся (или легендарное) Цетинское Четвероевангелие ${ }^{16}$.

Белградское Четвероевангелие было десять лет спустя перепечатано в монастыре Мркшина Црква (точное местонахождение неизвестно), скорее всего тем же иеромонахом Мардарием:

(N: 104; G: 24) Четвероевангелие, 24 июня 1562, 212 л., 39 экз. и фрагм.

B середине XVI века возрождается кирилловское книгопечатание на румынских землях, а одним из первых изданий этой группы является Апостол, напечатанный в Тырговиште внуком Божидара и сыном Феодора Любавича - Дмитрием Любавичем Логофетом. Стоит подчеркнуть, что это первая изданная на Балканах книга, содержащая текст Апостола (до этого Апостол был издан Франциском Скориной в Вильнюсе в 1525 г.). Издание имеет два варианта: валашский и молдавский (они отличаются прежде всего колофонами и упоминаемыми в них владетелями):

(N: 76) Апостол, 18 марта 1547, 268 л., 16 экз. и фрагм.

В румынских землях, одновременно с типографией Любавича-внука, в трансильванском городе Сибиу (Sibiu, Hermannstadt) действовала типография Филиппа Пиктора Молдаванина, где ок. 1544 года был издан напечатанный по-румынски кириллицей лютеранский катехизис, а также славянское Четвероевангелие, которое является практически дословной перепечаткой Тырговиштского Четвероевангелия 1512 года:

(N: 73) Четвероевангелие, 22 июня 1546, 300 л., 3 экз. и фрагм.

В этом же городе несколько лет позже был издан еще один схожий палеотип, хотя вопрос о датировке и месте этого издания не до конца ясен:

(N: 81; G: 1) Четвероевангелие, 1551-1554, 128 л., 2 экз. и фрагм.

Этот памятник, сохранившийся во фрагментах, содержит параллельный текст Евангелия на румынском и церковнославянском языках. По причине отсутствия выходных данных невозможно определить имя издателя, а исследователи (в том числе - авторы каталогов) связывают его как

\footnotetext{
${ }^{16}$ М. ПЕшиКАн, Лексикон српскославенског итампарства, [in:] Пет векова српског штампарства 1494-1994. Раздобље српскословенске штампе XV-XVII в., еd. М. ПАнтић, Београд 1994, p. 213.
} 
с Филиппом Молдаванином, так и с другим румынским издателем - дьяконом Кореси, с чьим именем связан также целый ряд валашско-румынских или валашско-болгарских (в более широком смысле - румыно-болгарских) изданий второй половины XVI в., среди которых не последнее место занимают библейские книги. Кореси работал в нескольких городах: в Тырговиште, Брашове, Себеше и в связи с этим вопрос локализации некоторых сохранившихся румыно-болгарских палеотипов, в которых отсутствуют выходные данные, не вполне ясен. Стоит также отметить, что дискуссионным считается вопрос и о конфессиональной принадлежности дьякона, поскольку он выпустил кирилловский румынский перевод Катехизиса Мартина Лютера.

На церковнославянском языке румыно-болгарской редакции дьяконом Кореси были выпущены следующие библейские книги:

(N: 106; G: 17) Евангелие, 13 октября 1562, 242 л., 8 экз. и фрагм.;

(N: 122; G: 40) Апостол, 15 декабря 1566, 320 л., 5 экз. и фрагм.;

(N: 134; G: 44) Псалтырь, ок. 1568/1570, 161 л., 2 экз. и фрагм.;

(N: 140; G: 55) Псалтырь с восследованием, ок. 1572/1573, 296 л., 2 экз. и фрагм.;

(N: 148; G: 63) Псалтырь, ок. 1576, 148 л., 2 экз. и фрагм.;

(N: 150; G: 65) Псалтырь, 1577, 316 л., 2 экз. и фрагм., книга содержит тексты на румынском и церковнославянском языках ${ }^{17}$;

(N: 151, G: 66) Псалтырь с восследованием, 1577, 172 л., 4 экз. и фрагм.;

(N: 156; G: 71) Псалтырь, ок. 1578, 337 л., 2 экз. и фрагм., книга содержит

тексты на румынском и церковнославянском языках;

(N: 158; G: 74) Евангелие, 1579, 206 л., 13 экз. и фрагм.;

(N: 165; G: 78) Псалтырь, ок. 1580, 156 л., 1 экз.;

(N: 180; G: 90) Четвероевангелие, ок. 1583, 202 л., 4 экз. и фрагм.

К румыно-болгарской традиции относится также деятельность типографа дьяка Лоринца, работавшего, скорее всего, независимо от дьякона Кореси. Среди его печатной продукции имеется изданное в трансильванском городе Алба-Юлия (Alba Iulia), называемом также Белградом или Балградом, Четвероевангелие:

\footnotetext{
${ }^{17}$ А. Гусева в своем каталоге пересказывает послесловие этого палеотипа: Послесловие: om тица печатника дьякона Кореси (по-румынски). В нем говорится, что все народы имеют на своих языках Слово Божие, а тишь румыны не имеют его на своем языке. Обращаясь к священникам, печатник говорит, что издал для них эту Псалтирь, переведя текст на румьнский язык с сербского издания. В заключение просит у читающих благословения и обозначает год печатания Псалтири - А.А. ГусевА, ор. сit., р. 501.
} 
(N: 157; G: 73) Четвероевангелие, 16 мая 1579, 211 л., 4 экз. и фрагм.

Последним из румынско-болгарских типографов, издававших библейские книги в XVI веке, был иеромонах Лаврентий, основатель монастыря св. Иоанна Крестителя на реке Колентина неподалеку от Бухареста. Его деятельность отражена прежде всего в двух изданиях Четвероевангелия, называемого в болгаристике „Лаврентиевото Четириевангелие” (в исследованиях на русском языке чаще встречается название „Бухарестское Евангелие”). Авторы сводных каталогов описывают это издание как два отдельных памятника, причем Гусева считает, что второе издание вышло не в Бухаресте, а в Брашове.

(N: 173; G: 86) Четвероевангелие, 1582, 218 л., 10 экз. и фрагм.

(N: 175: G: 88) Четвероевангелие, после 1582 г., более 240 л., 4 экз. и фрагм.

В новейших археографическо-языковых работах ${ }^{18}$ говорится о скорее всего двух изданиях одного и того же текста, а общее число известных на данный момент сохранившихся экземпляров составляет 19: 13 - первого издания и 6 - второго.

Д. Иванова, которая также исследовала язык Бухарестского евангелия (тем же методом хронологической проекции, о котором говорилось выше), подчеркивает, что среди особенностей этого памятника можно указать на новоболгарские инновации, характерные для восточноболгарских мизийских говоров. Эти явления, однако, немногочисленны и появляются на фоне очевидной тырновско-ресавской орфографии:

в езиково-правописно отношение търновската норма е доста стабилна, но в Лаврентиевото четириевангелие се наблюдава проникване на елементи от ресавски (или западнобългарски) тип, а също, макар и спорадично, са отразени явления и от говоримата реч (главно на фонетично и морфологично равнище) ${ }^{19}$.

Добавлю также, что в некоторых румынских работах с именем Лаврентия связывается также еще один библейский кирилловский палеотип - недатированная Псалтырь ${ }^{20}$. Мне не удалось, однако, обнаружить достоверных сведений, подтверждающих его существование.

Представленные выше основные составляющие и главные этапы южнославянской кирилловской старопечатной традиции (а также конкретные библейские издания) должны быть, конечно же, соотнесены с параллельной

\footnotetext{
${ }^{18}$ К. МАно-Зиси, Штампано „Четворојеванђете” Монаха Лаврентија. (Друго издағе, после 1582. године), АПри 25, 2003, р. 239-251; Д. ИвановА, Южноставянските печатни книги от XVI век и пътят кбм окончателната църковнославянска кодификация на библейския (евангелски) текст, [in:] Славянска филология 25. Сборник, посветен на XV славистичен конгрес в Минск, София 2013, p. 24-46.

${ }^{19}$ Д. Иванова, Традиция и приемственост..., p. 32.

${ }^{20}$ M. PĂCurariu, Dicţionarul teologilor români, ${ }^{2}$ Bucureşti 2002.
} 
восточнославянской традицией книгопечатания (намного лучше изученной), которую составляют: деятельность Франциска Скорины (ПрагаВильнюс, 1517-1525); деятельность т.н. анонимной типографии (Москва, ок. 1553-1565); деятельность Ивана Федорова (Москва-Заблудов-ЛьвовОстрог, 1564-1581); деятельность московских книгопечатников после отъезда из Москвы Ивана Федорова и появление Московского печатного двора (1568-); деятельность львовских (1591-1594) и острожских (ок. 1583-1612) книгопечатников после отъезда из этих городов Ивана Федорова; деятельность печатников Вильна: издательского дома Мамоничей (1574-1624), типографии Василия Гарабудры (ок. 1580-1582) и типографии Братства Св. Троицы / Св. Духа (1595-). Нет, однако, никаких сомнений, что недооценивание южнославянских палеотипических традиций XVI века может создавать не совсем адекватную картину истории славянского библейского текста, а также нести в себе опасность искажения нашего понимания тех процессов, которые легли в основу создания ново-церковно-славянского языка. Надеюсь, что палеославистике удастся этой опасности избежать.

\section{Библиография}

Nemirovsкij E.L., Gesamtkatalog der Frühdrucke in kyrillischer Schrift, vol. I, Inkunabeln, Baden-Baden 1996 (Bibliotheca Bibliographica Aureliana, 140).

Nemirovsкij E.L., Gesamtkatalog der Frühdrucke in kyrillischer Schrift, vol. II, Die Druckereien des Makarije in der Walachei und von Giorgio Rusconi in Venedig, Baden-Baden 1997 (Bibliotheca Bibliographica Aureliana, 152).

Nemirovskij E.L., Gesamtkatalog der Frühdrucke in kyrillischer Schrift, vol. III, Die Prager Druckerei von Francisk Skorina, Baden-Baden 1998 (Bibliotheca Bibliographica Aureliana, 155).

Nemirovskij E.L., Gesamtkatalog der Frühdrucke in kyrillischer Schrift, vol. IV, Die Druckerei von Božidar Goraždanin in Goražde und Venedig. Die erste Druckerei von Božidar Vuković in Venedig, Baden-Baden 2001 (Bibliotheca Bibliographica Aureliana, 170).

Nemirovsкij E.L., Gesamtkatalog der Frühdrucke in kyrillischer Schrift, vol. V, Die Druckerei von Francisk Skorina in Wilna, Baden-Baden 1999 (Bibliotheca Bibliographica Aureliana, 171).

Nemirovsкij E.L., Gesamtkatalog der Frühdrucke in kyrillischer Schrift, vol. VI, Die zweite Druckerei von Božidar Vuković in Venedig, Baden-Baden 2003 (Bibliotheca Bibliographica Aureliana, 187).

Nemirovskij E.L., Gesamtkatalog der Frühdrucke in kyrillischer Schrift, vol. VII, Die Klosterdruckereien in Rujno und Gračanica, Baden-Baden 2007 (Bibliotheca Bibliographica Aureliana, 207).

Păcurariu M., Dicţionarul teologilor români, ${ }^{2}$ București 2002.

Petrov I., Od inkunabułów do pierwszych gramatyk. Konteksty rozwoju bułgarskiego języka literackiego (koniec XV - początek XVII wieku), Łódź 2015. 
БогдАнов И., Българската книга през вековете, София 1978.

БогдАнов И., Български първопечатни книги от XVI-XVIII вв., ГББИ 9, 1963, p. 85-123.

Гусева А.А., Издания кирилловского шрифта второй половины XVI века. Сводный каталог, vol. I-II, Москва 2003.

Иванова Д., Традииия и приемственост в новобблгарските преводи на Евангелието. Текстотогия и език, Пловдив 2002.

Иванова Д., Южнославянските печатни книги от XVI век и пбтят кбм окончателната иърковнославянска кодификаиия на библейския (евангелски) текст, [in:] Славянска филология 25. Сборник, посветен на XV славистичен конгрес в Минск, София 2013, р. 24-46.

Круминг А.А., Сводный каталог старопечатных изданий глаголического шрифта 1483-1812 г2., Москва 1998.

МАно-Зиси К., Штампано „Четворојеванђеле” Монаха Лаврентија. (Друго издағе, после 1582. године), АПри 25, 2003, р. 239-251.

Мечковская Н.Б., Ранние восточноставянские грамматики, Минск 1984.

Немировски Е.Љ., Издаюа Божидара и Вићениа Вуковића, Стефана Мариновића, Јакова од Камене Реке, Јеролима Загуровића, Јакова Крајкова, Бованиа Антониа Рампацета, Марка и Бартоломеа Бинамиа (1519-1638), Цетиње 1993 (Црногорска библиографија, 1494 -1994 , t. 1, vol. 2).

НЕмировский Е.Л., Иван Федоров и его эпоха: энциклопедия, Москва 2007.

Немировский Е.Л., История славянского кирилловского книгопечатания XV - начала XVII века, vol. II, Начало книгопечатания у южных славян, pars 1-2, Москва 2005.

Немировский Е.Л., Сербские монастырские типографии 16 века, Москва 1995.

НЕмировский Е.Л., Славянские издания кирилловского (иерковнославянского) шрифта 14912000. Инвентарь сохранившихся экземпляров и указатель литературь, vol. I, 1491-1550, Москва 2009.

Немировский Е.Л., Славянские издания кирилловского (иерковнославянского) шрифта 14912000. Инвентарь сохранившихся экземпляров и указатель литературы, vol. II.1, 1551-1592, Москва 2011.

НЕмировский Е.Л., Славянские издания кирилловского (иерковнославянского) шрифта 14912000. Инвентарь сохранившихся экземпляров и указатель литературы, vol. II.2, 1593-1600, Москва 2012.

Пешикан М., Лексикон српскоставенског итампарства, [in:] Пет векова српског штампарства 1494-1994. Раздобъе српскословенске штампе XV-XVII в., еd. М. Пантић, Београд 1994.

САзОНова Л.И., Книги Кириллической печати во второй половине ХVI века меЖду Римом и Москвой, [in:] A.A. ГусевА, Издания кирилловского шрифта второй половины XVI века. Сводный каталог, vol. I-II, Москва 2003, p. 1242-1270.

Цивранска-Костова М., Етюди върху кирилската палеотипия XV-XVIII век, София 2007.

ЦиБрансКА-Костова М., Сборникбт „Различни потреби” на Яков Крайков между Венеция и Балканите през XVI век, София 2013. 


\begin{abstract}
Editions of the Biblical texts in the Cyrillic South Slavic tradition during the Sixteenth Century. The article is devoted to the printing Cyrillic South Slavic Biblical texts from the beginning (incunabula) until the early seventeenth century, along with the presentation and characteristics of the sources from Montenegro, Venice, Serbia, Wallachia and others. This history is referred to some Glagolitic sources and to the much better recognised history of Eastern Slavic paleotypy, both from the area of the First Republic of Poland, as well as from typographical centres of the Russian Tsardom.
\end{abstract}

Ключевые слова: Библия, глаголические и кирилловские инкунабулы, старославянские печатные издания, ново-церковно-славянский язык.

Keywords: Bible, Glagolitic and Cyrillic incunabula, old Slavic prints, New Church Slavonic language.

Ivan Petrov

Katedra Filologii Słowiańskiej

Centrum Ceraneum

Uniwersytet Łódzki

ul. Pomorska 171/173

90-236 Łódź

ivan.n.petrov@uni.lodz.pl 